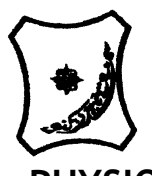

Bayero Journal of Pure and Applied Sciences: 10(1) 28 - 31

ISSN 2006 - 6996

\title{
PHYSIOLOGY OF COWPEA VARIETIES INTERCROPPED WITH SORGHUM BASED SYSTEMS IN THE SAVANNAH ECOLOGY OF NIGERIA
}

\author{
${ }^{* 1}$ Nuhu, Y. ${ }^{1 \& 2}$ Mukhtar, F. B. ${ }^{3 \& 4}$ Mohammed, I. B. and ${ }^{1}$ Hayatu, M. \\ ${ }^{1}$ Deparment of Plant Biology Bayero University Kano, \\ ${ }^{2}$ Federal University Dutse, Jigawa State \\ ${ }^{3}$ International Institute of Tropical Agriculture Kano, Nigeria \\ ${ }^{4}$ Department of Agronomy, Faculty of Agriculture, Bayero University, Kano \\ ${ }^{*}$ Correspondence author:ynuhu.bio@buk.edu.ng
}

\begin{abstract}
Six cowpea varieties (IT98K-131-1, IT04K-227-4, IT89KD-288, IT93K-452-1, IT97K-499-35 and IT99K-573-1-1) were intercropped with a local sorghum (Kaura) using four row arrangements $(1 C: 1 S, 2 C: 2 S$, Mixed crop and sole) in fields experiment conducted at Minjibir and research farm of the Faculty of Agriculture Bayero University Kano located in the Sudan Savannah ecological zone of Nigeria during the 2015 and 2016 rainy seasons. In the field, the experiment was laid in a randomized complete block design (RCBD), Analysis of variance (ANOVA) showed significant difference on cowpea cropping systems and variety on the physiology of cowpea. At BUK in both years and the combined, cowpea had higher non significant percent light interception at sole, at both sampling period's varieties IT98K-131-1 and IT93K-452-1 intercepted higher percent light compared with the other varieties similarly chlorophyll content was higher at sole, varieties IT97K-499-35, IT04K-227-4 and IT98K-131-1 had significantly higher chlorophyll content. At Minjibir in both years and the combined, sole row arrangement had the higher non significant percent light interception while variety IT89KD-288 had no significant higher light interception. In both trials, higher percent light interception was recorded in variety IT98K-131-1 and varieties IT04K-227-4 and IT97K-49935 had a significant combined effect on chlorophyll content.
\end{abstract}

Key words: Cropping systems, Cowpea varieties, Shading and physiology.

\section{INTRODUCTION}

Shading reduces the amount of solar radiation reaching the plants. Steindler et al., (2007) reported that shading corm for 21 days during the reproductive phase was more detrimental to grain production per plant than shading for longer periods during vegetative and maturation phases. Plants shaded at $60 \%$ or higher during the reproductive phase had a full complement of normal leaves but initiated and developed only a limited number of kernels. Innis (2000), found that shading soybeans for as little as 5 or 10 days could reduce the seed yield over $15 \%$ compared to the un shaded peanut., Steindler et al, (2007) reported that the peak flowering period was the period most sensitive to a reduction in solar radiation intensity.

\section{MATERIALS AND METHOD}

The study was conducted in fields experiment located in IITA farm at Minjibir local government Kano and the research farm of faculty of agriculture Bayero University Kano. One local variety of sorghum popularly known as Red Kaura was collected from institute for agricultural research Kano and six cowpea varieties namely 2 Erect IT93K452-1 and IT98K131-1, 2 Semi Erect IT97K-499-35 and IT04K-
227-4 and 2 Spreading type IT99K-573-1-1 and IT89KD-288 were collected from IITA Kano station... The fields planting were conducted on $19^{\text {th }}$ and $20^{\text {th }}$ July 2015 for the first experiment and $18^{\text {th }}$ June through $27^{\text {th }}$ June 2016 for the second experiment respectively at IITA Farm Minjibir local government, and Bayero university farm. Three cowpea seeds were sown per hole and were later thinned to two seedlings at three weeks after sowing; also three seeds of sorghum were intercropped with cowpea at 75 by $30 \mathrm{~cm}$ for $1 \mathrm{C}: 1 \mathrm{~S}$ and $2 \mathrm{C}: 2 \mathrm{~S}$ row arrangement and 75 by $20 \mathrm{~cm}$ for legume/cereal while for mixed crop it was 75 by $60 \mathrm{~cm}$ spacing. The experimental design used was Randomize Complete Block Design (RCBD) with three replication. Light interception reading (PAR) was taken by using ceptometre this was used at the upper leaves of the sorghum and then the reading was also taken under the legume plant leaves. Therefore, the upper reading minus the lower reading gives percent reduction in light caused by the shading of the sorghum on the cowpea; the readings were taken at the 3 and 6WAS respectively. Chlorophyll content was determined by using SPAD meter for each plot, readings were taken at the 3 and 6WAS. 


\section{RESULTS}

At BUK the effect of cropping system and variety on the light interception of cowpea in 2015, 2016 and the combined analysis is presented in Table 1a. Cropping system was not significant in 2015, 2016 and the combined but it increased progressively with age. Cowpea had higher percent light interception at sole compared with the other row arrangement while the least was 2C:2S row arrangement which was at par. The effect of cowpea variety on percent light interception in 2015 was significant but in 2016 and the combined analysis they were not significant although there was an increased of PAR with age. At both sampling period's varieties IT98K-131-1 and IT93K-452-1 intercepted higher percent light compared with the other varieties. Chlorophyll of cowpea was significantly affected by varieties in 2015 while it was not significant in 2016 and the combined analysis was significant. Irrespective of sampling periods and year sole row arrangement produced no significant and higher chlorophyll of cowpea than the other row arrangements. At all sampling stages in 2015, 2016 and the combined analysis IT97K-499-35, IT04K-227-4 and IT98K-131-1 had significantly higher chlorophyll compared with the other varieties. The interaction between the cropping system and variety on photosynthetic active radiation and chlorophyll was not significant. At MINJIBIR in 2015, 2016 and combined analysis Table 1b. Sole row arrangement had the higher non significant percent light interception followed by mixed crop compared to other row arrangements. Similarly varieties IT89KD-288 and IT99K-573-1-1 had no significant but greater percent light interceptions which were similar in values followed by IT97K-499-35 and IT93K-452-1 which were also at par with other varieties the lowest percent light interception was recorded on IT98K-131-1. Cropping system was also not significant on Chlorophyll in 2015, 2016 and the combined analysis thus sole had the greater chlorophyll content followed by mixed crop which was at par with the other row arrangements. Varieties had a significant effect on chlorophyll where IT04K-227-4 and IT97K499-35 had greater chlorophyll and IT98K-131-1 had the lowest chlorophyll in 2015 while in 2016 it was not significant, the combined analysis for the chlorophyll was significant. The interaction between the cropping system and variety on light interception and chlorophyll was not significant.

Table 1a: Effect of Cropping System and Variety on Light Interception (\%) and Chlorophyll Content (ugm- ${ }^{2}$ ) of Cowpea at BUK, 2015, 2016 and Combined.

\begin{tabular}{|c|c|c|c|c|c|c|}
\hline \multirow[t]{2}{*}{ Treatment } & \multicolumn{3}{|c|}{ Light interception } & \multicolumn{3}{|c|}{ Chlorophyll content } \\
\hline & 2015 & 2016 & COMBINED & 2015 & 2016 & COMBINED \\
\hline \multicolumn{7}{|l|}{ Cropping system } \\
\hline $1 \mathrm{C}: 1 \mathrm{~S}$ & 224.9 & 343.5 & 284.2 & 76.84 & 53.04 & 64.94 \\
\hline $2 C: 2 S$ & 226.7 & 309.3 & 268.0 & 78.64 & 59.62 & 69.13 \\
\hline Mixed crop & 238.2 & 377.8 & 308.0 & 75.28 & 58.35 & 66.81 \\
\hline Sole & 255.8 & 405.7 & 330.8 & 82.96 & 83.14 & 83.05 \\
\hline Lsd & 36.1 & 30.59 & 27.06 & 12.6 & 7.37 & 9.27 \\
\hline \multicolumn{7}{|l|}{ Variety } \\
\hline IT98K-131-1 & $254.6 a$ & 375.8 & 315.2 & $70.38 c d$ & 72.73 & $71.55 b c$ \\
\hline IT04K-227-4 & $190.6 \mathrm{~b}$ & 354.8 & 272.7 & $87.86 \mathrm{~b}$ & 66.08 & $76.97 a b$ \\
\hline IT89KD-288 & $238.2 a$ & 375.0 & 306.6 & $59.73 d$ & 54.36 & $57.04 f$ \\
\hline IT93K452-1 & $252.3 a$ & 356.2 & 304.3 & $75.18 b c$ & 56.54 & $65.86 c-f$ \\
\hline IT97K499-35 & $251.4 a$ & 350.8 & 301.1 & $104.22 \mathrm{a}$ & 66.80 & $85.51 \mathrm{a}$ \\
\hline IT99K-573-1-1 & $231.3 a b$ & 341.8 & 286.6 & $73.22 \mathrm{bcd}$ & 64.74 & $68.98 \mathrm{bcd}$ \\
\hline LSD & 43.7 & 37.46 & 30.32 & 15.4 & 9.03 & 9.7 \\
\hline$P C V^{*} V$ & NS & NS & NS & NS & NS & NS \\
\hline P CV*LOC & NS & NS & NS & NS & NS & NS \\
\hline P V/LOC & NS & NS & NS & $*$ & $*$ & $*$ \\
\hline
\end{tabular}

Means followed by the same letters in a column are not statistically significant using LSD at $5 \%$ level of probability 
Table 1b: Effect of Cropping System and Variety on Light Interception (\%) and Chlorophyll Content (ugm- ${ }^{2}$ ) of Cowpea at MINJIBIR, 2015, 2016 and Combined.

\begin{tabular}{|c|c|c|c|c|c|c|}
\hline & ght & & & ophyll con & & \\
\hline $\begin{array}{l}\text { Treatment } \\
\text { Cropping system }\end{array}$ & 2015 & 2016 & COMBINED & 2015 & 2016 & COMBINED \\
\hline $1 \mathrm{C}: 1 \mathrm{~S}$ & $156.4 \mathrm{~b}$ & $277.7 b c$ & 217.1 & 57.95 & $62.74 \mathrm{~b}$ & 60.35 \\
\hline $2 C: 2 S$ & $137.9 \mathrm{~b}$ & $264.1 \mathrm{c}$ & 201.0 & 56.13 & $61.01 \mathrm{~b}$ & 58.57 \\
\hline Mixed crop & $151.1 \mathrm{~b}$ & $293.4 b$ & 222.3 & 63.65 & $60.75 b$ & 62.20 \\
\hline Sole & $229.4 a$ & $315.4 a$ & 272.4 & 61.0 & $89.29 a$ & 75.14 \\
\hline LSD & 22.0 & 19.56 & 27.06 & 9.92 & 11.81 & 9.27 \\
\hline Variety & & & & & & \\
\hline IT98K-131-1 & 159.7 & 281.9 & 220.8 & $47.11 \mathrm{c}$ & 71.29 & $59.20 \mathrm{ef}$ \\
\hline IT04K-227-4 & 167.2 & 280.5 & 223.8 & 68.98ab & 70.28 & $69.63 \mathrm{bcd}$ \\
\hline IT89KD-288 & 166 & 308.7 & 237.4 & $53.4 \mathrm{c}$ & 67.0 & $60.2 \mathrm{ef}$ \\
\hline IT93K452-1 & 171.0 & 282.4 & 226.7 & $59.16 \mathrm{bc}$ & 69.50 & $64.33 c-f$ \\
\hline IT97K499-35 & 176.9 & 275.8 & 226.4 & 79.51a & 54.95 & $67.23 \mathrm{cde}$ \\
\hline IT99K-573-1-1 & 171.2 & 296.5 & 233.8 & $49.92 c$ & 77.61 & $63.76 c-f$ \\
\hline LSD & 26.9 & 23.95 & 30.32 & 12.1 & 14,46 & 9.7 \\
\hline $\mathrm{PCV} / \mathrm{V}$ & NS & NS & NS & NS & NS & NS \\
\hline P CS/LOC & NS & NS & NS & NS & NS & NS \\
\hline $\mathrm{P} V / \mathrm{LOC}$ & NS & NS & NS & * & * & * \\
\hline
\end{tabular}

Means followed by the same letters in a column are not statistically significant using

LSD at $5 \%$ level of probability

\section{DISCUSSION}

There were variations in the performance of the test crop (cowpea) with respect to its physiology characters across the two years of fields study. This could be related to the amount of rainfall recorded in each year and the effects of shading. kassam and kowal (1973) reported that rainfall is the most important weather factor affecting crop production in the savannah. High soil moisture is known to enhance nutrient availability and uptake, which in turn supports large leaf canopy, high light interception and improved biomass production (Richards, 2000). The highest light interception and chlorophyll content recorded by cowpea plants under sole row arrangement at BUK could be because cowpea plants had no stressed which means they had a wider space for light interception and hence were able to produce leaves with large leaf area.Ajeibe et al (2006). At Minjibir the highest plant height, leaf area and leaf area index of cowpea recorded under sole row arrangement could be because at wider arrangement cowpea plants

\section{REFERENCES}

Ajeigbe, H.A., Singh B.B. and Oseni T.O., (2006). Effect of planting pattern, crop variety and insecticide on the productivity of cowpea - cereal systems in northern guinea savanna of Nigeria, IITA Kano Station. Journal of food, were able to intercept more photosynthetic active radiation for wider plant height, leaf area and leaf area index. As such Competition for light among component crops has been identified as the major reason for low dry matter production of cowpea in the mixtures, Bandyopadhyay and De, (1986).

\section{CONCLUSION}

Across the years at BUK sole and $1 \mathrm{C}: 1 \mathrm{~S}$ and varieties IT89KD-288 and IT93K-452-1 had the highest PAR. While chlorophyll content was also higher in sole and 2C:2S and varieties IT97K499-35 and IT04K-227-4 had the greatest chlorophyll content respectively. Also across the years at MINJIBIR the PAR was higher in sole and mixed crop and also higher in varieties IT99K-573-1-1 and IT97K-499-35, the chlorophyll content of MINJIBIR was also superior in sole and mixed crop and varieties IT04K-227-4 and IT97K-499-35 had the greatest chlorophyll content. In both trials, PAR and chlorophyll content plays a vital role in higher growth and yields parameters of the varieties studied.

agriculture and environment vol. 4(1): pg. 101 - 107.

Bandyopadhyay, S.K. and De, R. (1986). Plant growth and seed yield of soybean when intercropped with legumes. Journal of Agricultural Science (Cambridge). 107: 621-627. 
Innis, D.Q (2000). Intercropping and scientific basis of traditional agriculture. Intermediate

Kassam, A.H. and Kowal, J. M. (1973). Productivity of crop in the savanna and rain forest zones of Nigeria. Savanna. Vol. 2 No.1. June 1973.

Kassam, A.H. and Kowal, J. M. (1973). Productivity of crop in the savanna and rain forest zones of Nigeria. Savanna. Vol. 2 No.1. June 1973.

Richards R. A. (2000). Selected traits to increase crop photosynthesis and yield of grain crops. Journal of Experimental
Botany, Vol. 51, No. 90001 , pp. 447458.

Steindler C, Matteucci A, Sessa G, Weimar T, Ohgishi M, Aoyama T, Morelli G, Ruberti I (2007) Shade avoidance responses are mediated by the ATHB-2 HD-Zip protein, a negative regulator of gene expression. Development 126: 42354245.

Trenbath, B.R. (1972). Ph.D. Thesis. Univesity of Adelaide. Cited by Trenbath, B.R. In Biomass productivity of mixtures. Advances in Agronomy 26: 177-210. 